IJLR: International Journal of Law Recontruction

Volume 5, Number 2, September 2021

DOI : http://dx.doi.org/10.26532/ijlr.v5i2.17706

\title{
THE JUDICIAL POWER LIMITATION OF COMMERCIAL COURTS COMPETENCY IN COMMERCIAL DISPUTES
}

\author{
Sobandi \\ Universitas Mahendradatta Denpasar \\ ki.sobandi@gmail.com
}

\begin{abstract}
One of the important instruments in a state of law is the existence of an independent judiciary, whether it is based on the doctrine of separation of powers, the notion of a state based on law or democracy. An independent judicial power is not absolute in the sense that it is free to lead to arbitrariness so that there must be restrictions on that power and freedom. The approach method is used a normative juridical approach. The results of the study found that the limitations of judicial power were based on the constitutional basis, namely Article 1 paragraph 3 of the 1945 Constitution, Article 24 of the 1945 Constitution and Article $24 \mathrm{~A}$ of the 1945 Constitution. From the concept of separation or division of powers, compose an independent judicial power which is exercised by a Supreme Court and judicial bodies under it and a Constitutional Court. The commercial court as a sub-system within the judicial power is a special court under the general judiciary that has different competencies from other general courts. The implementation of the limitation of judicial power in the competence of the commercial court to realize an independent judicial power is normatively spread out in various laws.
\end{abstract}

Keywords: Commercial; Court; Judicial; Limitation; Power.

\section{A. INTRODUCTION}

The Indonesian nation was born according to the way and the way it took itself. The result of historical processes in the past, about the struggles and ideals of life in the future which as a whole shape his personality. The Indonesian nation was born with a number of characteristics, traits and values that it has had since ancient times so that it distinguishes the Indonesian nation from other nations ${ }^{1}$. The state of Indonesia is a country that upholds the values of justice for each of its people, in order to provide a sense of justice for the entire community, the constitution states that the state of Indonesia is a state of law. Article 1 paragraph (3) of the 1945 Constitution of the Republic of Indonesia, hereinafter referred to as the 1945 Constitution expressly states that Indonesia is a state of law. The state of law in question is a state that upholds the rule of law to uphold truth and justice and there is no irresponsible power. ${ }^{2}$

1 Kaelan, Filsafat Pancasila Pandangan Hidup Bangsa Indonesia, Paradigma, Yogyakarta, 2009, page. 175.

2 Majelis Permusyawaratan Rakyat Republik Indonesia, Panduan Pemasyarakatan UndangUndang Dasar Republik Indonesia Tahun 1945 (Sesuai dengan urutan Bab, Pasal dan ayat), Sekretaris Jendral MPR RI, Jakarta, 2010, page.46. 
One of the important instruments in a state of law is the existence of an independent judiciary. This is also in line with various international conventions, including: United Nation Declaration of Human Rights, 1948 in Article 10 states: "everyone is entitled in full equality in a fair and public hearing by an independent an impartial tribunal, in the determenitation of his rights an obligation and of any criminal charge against him".

International Covenant Civil and Political Rights, Article 14 paragraph (1) states: "All person shall be equal before the courts and tribunal. In the determination of any criminal charge agains hims, or of his rights and obligation in a suit of law, everyone shall be entiled to fair and public earing by competent, independent and impartial tribunal established by law."

The two international conventions emphasize that judicial power is one of the main components in the rule of law. The judicial power referred to in the convention is an independent, impartial and competent judicial power. ${ }^{3}$ Bagir Manan explained that there are 5 (five) general conceptual bases for judicial power to be independent or independent, namely the doctrine of democracy, the rule of law, the teaching of human rights, the teaching of a constitutional state, and the doctrine of separation of powers. ${ }^{4}$ Furthermore, Bagir Manan explained that, ${ }^{5}$ In the teachings of democracy where the people are sovereign, to supervise or control the administration of the state is subject to the will of the people and does not exceed authority or arbitrarily, in addition to using political mechanisms, the people can sue state administrators before an independent court. In the teachings of the rule of law, one of the important elements of the rule of law is that there is a judicial power that is independent, impartial (impartiality) and fair (fairness). In the teaching of human rights, to guarantee the protection of human rights, there must be a neutral and impartial institution or procedure, namely an independent judicial power. In the teachings of a constitutional state, deviations from the provisions of the constitution are unconstitutional actions that must be corrected, either through political mechanisms (such as checks and balances), or legal mechanisms through neutral and impartial judicial powers. In the teaching of separation of power, it is the limitation of power and independence of each branch of power, namely the legislative, executive and judiciary through a system of checks and balances so that the independence of judicial power is a consequence of the independence of each branch of power.

There are restrictions on state power and state organs by applying the principle of vertical power sharing or horizontal separation of powers. In accordance with the iron law of power, every power must have a tendency to develop arbitrarily, as stated by Lord Acton: "Power tends to corrupt, and absolute power corrupts absolutely". The guarantee of the independence of judicial power in Indonesia as a state of law is provided by the constitution, which is contained in Article 24 paragraph (1) of the 1945 Constitution

\footnotetext{
3 Bagir Manan, Prasyarat Kemerdekaan Kekuasaan Kehakiman, Varia Peradilan Majalah Hukum Year XXX No.348 November 2014, page.10-12

4 Ibid.

5 Ibid.
} 
which states that: "Judicial power is an independent power to uphold law and justice."

According to Dr. Ridwan, the conception of Indonesia's legal state is the state of Pancasila. ${ }^{6}$ Hadjon, stated the important elements of the Indonesian legal state based on Pancasila, namely: ${ }^{7}$

1. Harmony of relations between the government and the people based on the principle of harmony;

2. The proportional functional relationship between state powers;

3. Settlement of disputes through deliberation and the judiciary as a last resort if deliberation fails;

4. Balance between rights and obligations.

Furthermore, according to Hadjon, based on these elements, legal protection efforts for the community are directed at: 8

1. Efforts to prevent disputes or reduce disputes so that preventive legal protection facilities need to be prioritized over repressive protection;

2. Efforts to resolve disputes between the government and the people through deliberation and full kinship;

3. Settlement of disputes through the judiciary is a last resort and not a forum for confrontation, so that a peaceful and peaceful atmosphere must be reflected from it through the procedural law.

Judicial power, both in doctrine and according to law, is held and exercised by the judiciary. ${ }^{9}$ The administration of a judicial institution which is the exercise of power in the field of justice in a state of law, the state of law in question is a state that places judicial power as an independent power, respects human rights and the principle of due process of law. ${ }^{10}$ In Indonesia, the judicial bodies that exercise judicial power under the 1945 Constitution are the Supreme Court, the Constitutional Court, and lower courts under the Supreme Court. Article 25 of Act No. 48 of 2009 concerning Judicial Power states that judicial bodies under the Supreme Court include general courts, religious courts, military courts and state administrative courts.

The perpetrators of judicial power in both the Supreme Court and the Constitutional Court are judges. In Article 1 of the Law on Judicial Power, the definition of judges in the Indonesian judiciary is divided into 4 (four) namely judges, supreme judges, constitutional judges and ad hoc judges. In the constellation of community life, nation and state, the judiciary has a very important normative and sociological function. The judiciary in Indonesia is to enforce the law for the sake of the law itself, as stated by

6 Ridwan, Reorientasi Penggunaan Diskresi: Kajian tentang Kontrol Penyelenggaraan Pemerintahan Melalui Pejanjian Kebijakan (Beleidsovereenkomst), Disertasi, Program Doktor Ilmu Hukum Universitas Diponegoro Semarang 2012, page.83.

7 Ibid, page. 90

8 Moh.Mahfud MD., Membangun Politik Hukum, Menegakkan Konstitusi, Raja Grafindo Persada, Jakarta, 2011, page. 189-190.

9 M. Yahya Harahap, Kekuasaan Mahkamah Agung Pemeriksaan Kasasi dan Peninjauan Kembali Perkara Perdata, Sinar Grafika, Jakarta, 2008, page. 1.

10 Dachran Busthami, Kekuasaan Kehakiman dalam Perspektif Negara Hukum di Indonesia, Masalah-Masalah Hukum, Vol. 46 No. 4, October 2017, page.336-342 
Oliver Wendell Holmes "the supreme court is not a court of justice, it is a court of law". Court to enforce the law for the sake of justice, both for individuals, as well as society, nation, and state. ${ }^{11}$

Law is the lifeblood of a nation to achieve the ideals of a just and prosperous society. Muladi said that since Indonesia's independence, the theme of the rule of law has received the most attention, partly due to the apparent weakness in the legal institutions themselves, legal institutions (judicial institutions) are not functioning as they should, namely according to the level of wishes, expectations, and demands of the people. from almost all levels of society. The law plays a role in maintaining the judiciary as an institution to provide a sense of justice for justice seekers, lest the judiciary lose its true spirit because of globalization, the judiciary will also be affected by globalization.

This was revealed by Hilario G. Davide Jr. (Chief Justices of the Court of the Republic of the Philipines), 12 "Globalization is the economic movement of the future. The Global World offers many opportunities to achieve an independent judiciary. In a catchy sentence, it also contains a real trap that will erode the independence of the judiciary itself."

Donald Black called the law is social control from the government (law is governmental social control) so that the legal system is a social control system in which the structure, institutions, and processes of social control are regulated. ${ }^{13}$ Friedman also mentions that the most important is the function of the law itself, namely as social control, dispute resolution, good distributing scheme, and social maintenance. ${ }^{14}$ The role of the court can no longer be doubted, because with this judicial institution, everything that concerns neglected rights and responsibilities can be resolved, this institution provides a place and even helps those who feel that their rights have been deprived of them and force the parties to take responsibility for their actions to the detriment of the other party. ${ }^{15}$ This court institution in addition to being an institution that provides a sense of justice for people who want to get justice. This is what proves that the Indonesian state is a state of law, so the presence of a court institution is very necessary in the life of society, nation and state.

There is no doubt that the task of a judge is to adjudicate according to the law every case presented to him in the fairest way possible, without discriminating against people based on ethnicity, religion, race and class, position and wealth. The main task of a judge is to uphold justice, not legal

11 Antonius Sudirman, Hati Nurani Hakim dan Putusannya Suatu Pendekatan Dari Perspektif IImu Hukum Perilaku (Behavioral Jurisprudence) Kasus Hakim Bismar Siregar, Citra Aditya Bakti, Bandung, 2007, page. 1.

12 Hilario G.Davide, Jr.,Comments on the Paper of Hon. Andrew Kwok Nang Li, Chief Justice of the Court of Final Appeal of the Hongkong Special Administrative Region of the People S Republic of China, Conference of Chief Justices of Asia and Pacific, 18th Law Asia Conference, Seoul, 8 September 1999, page.1

13 Donald Black, The Behaviour of Law, Academic Press, New York USA, 1976, page.5

14 Lawrence Friedman, American Law, An Introduction, W.W. Norton \& Company, New York, 1984, page. 5-14.

15 Rusli Muhammad, Lembaga Pengadilan Indonesia Beserta Putusan Kontroversial, UII Press, Yogyakarta, 2013, page. 3. 
certainty, even K. Wantjik Saleh explained that the work of judges is based on justice. ${ }^{16}$

Court achievements can be measured by how the court is able to carry out its duties and functions in the context of law enforcement and justice. If it turns out that the court is acting in accordance with its duties and functions, it means that it has shown good performance, but if it is the other way around, it means that it has not been able to provide good achievements in society. ${ }^{17}$

The purpose of this paper is to find out and analyze the limitations of judicial power in the application of law in commercial courts, although in principle judicial power must be independent and judges have freedom, but independent judicial power and freedom itself are not absolute in the sense of being free without limits. In fact, it can lead to arbitrariness so that of course there are restrictions on these powers and freedoms as described above.

\section{B. RESEARCH METHODS}

Based on the paradigmatic, legal research can be categorized into several types, namely normative legal research, empirical legal research, hermeneutic legal research, and epistemological anarchism legal research. ${ }^{18}$. Seeing its consistency with the problems studied, this legal research is classified as legal hermeneutic research. ${ }^{19}$ By paying attention to the legal issues that are reflected in the judicial power of the study of commercial justice in Indonesia. To find answers to the question of implementing the competence of commercial courts in Indonesia in dealing with disputes in the commercial sector and how to limit the ideal competence for commercial courts in upholding judicial power. In addition to using the normative approach method but also using the social approach method, namely by conducting research or research, because research or research means searching in the form of finding answers to a problem. ${ }^{20}$ Which belongs to the social or empirical research group, with this model it is possible to reveal the legal behavior implemented by law enforcement officials, especially judges in solving commercial problems in Indonesia.

\section{RESULTS AND DISCUSSION}

\section{Limitation Of Judicial Power of Justice Concept}

The definition of judicial limitation is a limitation on power carried out by patterns of restrictions in the internal management of state power itself, namely by making distinctions and separation of state power into

16 K. Wantjik Saleh, Kehakiman dan Peradilan, Ghalia Indonesia, Jakarta, 1977, page. 39.

17 Rusli Muhammad, Op.Cit, page. 23.

18 Muhammad Syaifuddin, Menggagas Hukum Humanistis-Komersil, Upaya Perlindungan Hukum Hak Masyarakat Kurang Mampu dan Tidak Mampu atas Pelayanan Kesehatan Rumah Sakit Swasta Bebadan Hukum Perseroan Terbatas, Bayu Media, Publishing, 2009, page. 59-60.

19 Gregory Leyh, Hermeneutika Hukum, Nusa Media, Bandung, 2008, page. 127.

20 Soetandyo Wignjosoebroto, Hukum Paradigma, Metode dan Dinamika Masalahnya, ELSAMHUMA, Jakarta, 2002, page. 123. 
different functions. In this connection, the one who can be considered the most influential in his thinking in distinguishing the functions of power is Montesquieu with his Trias Politica theory. These are the legislative branch of power, the executive or administrative branch of power, and the judicial branch of power. The term limitation was put forward by Anthony Allot, the law has limits in its effectiveness, there is a general tendency in various countries to make laws and regulations, and it is difficult to measure the effectiveness of the law.

In essence, judicial power is one of the important elements in the constitutional structure that is part of the legal system of a country. In the concept of the rule of law, including the concept of rechtstaat, as well as the rule of law, as well as Islamic nomocracy, judicial power becomes a pillar of support for one pillar and an important element that supports a working state of law. In a state of law, judicial power is required to be free or independent from anyone's influence. Judicial power must also be independent, separate from other powers, namely legislative power and executive power. ${ }^{21}$

Independent judicial power is one of the principles of a democratic rule of law, then the independence is given to the judiciary as the organizer and the judge personally as the executor of judicial power. An independent judiciary is needed solely because of its function in administering the judiciary to enforce law and justice. ${ }^{22}$

Legal principles or principles called freedom or independence of judicial power or freedom or power of the judiciary and judges do not only apply in Indonesia. Even in the international world, therefore, this principle is a universal principle, because it is universally adopted by countries in the world. As stipulated in the Beijing Statement of Principles on the Independence the Law Asia Region of the Judiciary in Manila on August 28, 1997, it was emphasized that:

a. The judiciary is the highest value institution in every society.

b. The independence of judges requires that judges decide a case entirely on the basis of understanding the law and free from influence from anywhere, either directly or indirectly, judges have jurisdiction over all issues that require justice. ${ }^{23}$

The 1945 Constitution of the Republic of Indonesia requires judicial power to be independent in order to enforce law and justice. This is regulated in Article 24 paragraph (1) explaining that the judicial power is an independent power that administers the judiciary to enforce law and justice. Article 24 paragraph (1) above, then comes the necessity to revise Act No. 35 of 1999 with Act No. 4 of 2004 and then revised again with Act No. 48 of 2009 concerning Judicial Power, regulating the same

21 Dahlan Sinaga, Kemandirian dan Kebebasan Hakim Memutus Perkara Pidana dalam Negara Hukum Pancasila Suatu Perspektif Teori Keadilan Bermartabat, Nusa Media, Bandung, 2015, page.1.

22 Ahmad Fadlil Sumadi, Pengawasan dan Pembinaan Pengadilan Fungsi Manajemen Mahkamah Agung Terhadap Pengadilan di Bawahnya Setelah Perubahan UUD 1945, Setara Press, Malang, 2013, page. 64.

23 Dahlan Sinaga, Op.Cit., page. 7. 
thing.

The guarantee regarding the freedom or independence of judicial power in Act No. 48 of 2009 is regulated in Article 1 which explains that "judicial power is the power of an independent state to administer justice in order to enforce law and justice based on Pancasila, for the sake of the implementation of the legal state of the Republic of Indonesia".

Effendi Lotulung explained that a free and independent judicial power in a state based on Pancasila law has two meanings: first; judicial power is free and independent from intervention from any party. In the sense that the judicial power is not only free from intervention from the executive and legislative powers, but also free from the intervention of the litigants, the press, public opinion, and so on. Even the judicial power must also be free from the intervention of the judicial power itself, for example from higher judicial powers. Second; Judicial power that is free and independent is only intended for the function of the judiciary as the executor of judicial power, namely when the judicial power carries out its judicial function in establishing concrete laws or in other words free and independent in deciding a case. ${ }^{24}$

The meaning of an independent and free judicial power has a functional dimension. Functional in the sense that such meaning guides the implementation of the functions of judicial power in resolving disputes, whether civil, criminal, state administrative disputes and so on. Judges apply laws that are sourced from the applicable laws and regulations, provided that the relevant laws and regulations are appropriate and correct to treat the cases being examined. In the perspective of the substance of the law enforced by the judiciary as a service of justice to the community, there is an expansion of the scope in terms of the law being enforced, so that the law enforced covers all laws in its hierarchical system, including constitutional law for which a new judicial power actor is formed, the Constitutional Court, which enforces constitutional law, namely regarding the constitutional rights of citizens, both in the social, economic, political, and cultural fields. as follows:

Kelsen and Rawls generally explain the formal elements of justice

a. Justice is a value that directs each party to provide protection for the rights guaranteed by law (the element of rights);

b. This protection must ultimately provide benefits to each individual (benefit element). ${ }^{25}$

Herlien Budiono explained the unique meaning of justice in Indonesia and its scope in national law. The meaning of justice which can be distinguished into procedural meaning and substantive meaning, is embedded and rooted in the condition of society. The procedural

24 Piatur Pangaribuan dan Arie Purnomosidi, Negara Hukum Pancasila dalam Kerangka NKRI, Cakrawala Media, Surakarta, 2014, page. 341

25 Jogi Nainggolan, Energi Hukum sebagai Faktor Pendorong Efektivitas Hukum, Refika Aditama, Bandung, 2015, page. 52-53. 
meaning of justice relates to the legal system or the rule of law. In contrast, the substantive meaning of justice is related to social conditions, which provide an overview of legal politics and legal awareness of the community. The relationship between the two meanings of justice depends on the choice of the legitimacy of the principles that underlie life together or by establishing a pattern of values as the basis for material criteria for the meaning of justice. ${ }^{26}$

Although the law must first be able to enforce order, the end goal is the development of justice, if possible, even if it is equally for everyone. Order without a further purpose may be an unjust order, just as an order with a purpose other than justice may exist. ${ }^{27}$

Aristotle distinguishes justice into two, namely general justice and special justice, two terms that will repeatedly rise to the fore in history as iustitia generalis and iustitia particularis (or iustitia specialis). General justice is justice that applies in general, which may be understood as 'all for all' which will not necessarily become clear when it enters the individual domain. While special justice is divided into two, namely justice in the distribution of necessities or what is known as iustitia distributiva with respect to how similar or how different someone receives something compared to other people in terms of the necessities of life. Justice in transactions between citizens or what is known as iustitia correctiva with regard to fair or unfair transactions which are further divided into voluntary transactions and involuntary transactions. ${ }^{28}$

However, the issue of the independence of the judiciary has actually been discussed for a long time. The function of the court as the last bastion to obtain justice has long been coveted by all levels of society without exception. The ideal court institution is an institution that can absorb people's aspirations about the meaning of justice and the legal needs of the community which will later be translated into decisions that will be handed down. ${ }^{29}$

The increasingly widespread legal speculation will lead the community to the stage, namely the stage of a state without legal certainty. A country that does not have legal certainty will find it very difficult to present itself as a state of law, with all the consequences that will only harm its own people. ${ }^{30}$ So that the judicial power runs according to the constitution and laws and regulations. Because basically the Judicial Institution is only limited to providing considerations and decisions based on the law, as well as the judge's belief in a sense of justice.

26 Herlien Budiono, Asas Keseimbangan Bagi Hukum Perjanjian Indonesia: Hukum Perjanjian Berlandaskan Asas-Asas Wigati Indonesia, Citra Aditya Bakti, Bandung, 2006, page.117.

27 Budiono Kusumohamidjojo, Teori Hukum Dilema antara Hukum dan Kekuasaan, Yrama Widya, Bandung, 2016, page. 267.

28 Ibid.

29 Zaenal Ma'arif, Politik dan Peradilan Sikap dan Tanggapan Kekuasaan Eksekutif terhadap Putusan Pengadilan di Bidang Politik, Genta Publishing, Yogyakarta, 2015, page. 25.

30 Budiono Kusumohamidjojo, Op.Cit, page. 298. 


\section{Limitation Of Judicial Power In Commercial Court Competence}

The ideals of an ideal legal state in accordance with the values that live in the Indonesian nation have begun to be formulated by the founding fathers and mothers of the Unitary State of the Republic of Indonesia since the independence era and reformulated during the reform era. The idea of a state of law or in other terms nomocracy cannot be separated from the influence of other legal state concepts such as Islamic Nomocracy, Rechtstaat, Rule of Law, and Legal Socialists that are developing in the world so that it affects the conception of the ideal of a state of law in Indonesia which is currently better known and recognized. as the State of Pancasila Law. Jimly Asshidiqie tries to compare the idea of nomocracy with the idea of democracy by looking at it in terms of etymology (word formation), namely nomocracy comes from Greek which consists of the words nomos and kratos, nomos has the meaning of norm and kratos has the meaning of power so that it can be said that nomocracy is closely related to the idea the rule of law or the principle of law as the highest power in a country. ${ }^{31}$

Judicial power as a judicial institution is the spearhead in the process of law enforcement its legitimacy in society as a means of law enforcement and justice, this has awakened us from daydreams and to reorganize judicial power as an impartial and independent institution. Thinking towards how to develop a judicial system in Indonesia that is more systematically organized and integrated into an integrated justice system, seems to be an option that needs to be done, considering that the judiciary is the guardian of law enforcement and justice. ${ }^{32}$

An independent judicial power is closely related to the notion of limiting power, whether originating from the teachings of the separation (division) of power, understanding the state based on law or democracy. According to the understanding of the separation of powers (Montesquieu), the separation of powers is needed as a means of limiting power to prevent arbitrariness. Power in one hand will lead to arbitrary actions. ${ }^{33}$ According to Montesquieu: "...there is no liberty, if the judiciary power be not separated from the legaslative and executive". George Hamilton: "there is no liberty, if the power of judging be not separated from legislative and executive" ${ }^{34}$.

The two expressions of the two figures above reflect that the trias politica (separation of power) is related to the guarantee and protection of public liberty. The separation of powers as a method of limiting power, is intended to prevent tyranny. The relationship between separation of power and independent judicial power and the freedom of judges is fairness and impartiality, so to ensure that a dispute over a violation of

31 Jimly Asshidiqie, Konstitusi dan Konstitusionalisme Indonesia, Sekretariat Jenderal dan Kepaniteraan Mahkamah Konstitusi, Jakarta, 2006, page.151.

32 Faridy, Menuju Kekuasaan Kehakiman Yang Bebas dan Mandiri, HAKAM, Vol 02 No 02, December 2018, page.118-138

33 Rimdam, Kekuasaan Kehakiman Pasca-Amandemen Konstitusi, Kencana Prenada Media Group, Jakarta, 2012, page. 12.

34 Ibid. 
the law can be resolved fairly and impartially, a neutral judiciary and judges are needed. That is why judicial power must be separated from the legislature. and the executive or the influence of other powers, namely to ensure neutrality, impartiality and fairness so that separate judicial powers must be independent and there is freedom of judges.

The independence of the power of the judiciary cannot be separated from the theoretical debate on the separation of powers, the separation of powers from the branches of state power is intended to guarantee the independence of the judiciary's power as well as to ensure the implementation of political freedom for members of the public in the state, so there is a guarantee of power. An independent judiciary is an important element of the rule of law concept.

The limitation of judicial power is based on the constitutional basis, namely Article 1 paragraph 3 of the 1945 Constitution, Article 24 of the 1945 Constitution and Article 24 A of the 1945 Constitution. Indonesia as a state based on Pancasila law has the goal of realizing social justice for all Indonesian people, and as a manifestation of the concept of separation or The division of powers constitutes an independent judicial power which is exercised by a Supreme Court and its subordinate judicial bodies and a Constitutional Court. The commercial court as a sub-system within the judicial power is a special court under the general judiciary that has different competencies from other general courts. The implementation of the limitation of judicial power in the competence of the commercial court to realize an independent judicial power is normatively spread out in various laws.

These norms include legal remedies against decisions of commercial court judges that eliminate appeals, the supervisory function by the Supreme Court internally and the Judicial Commission and the general public externally, judges' code of ethics, competence of judges and commercial court institutions, court procedural law, commerce, principles and integrated components that will strengthen the commercial court. As a court that is given the authority to examine and decide disputes in the commercial sector.

The competence of the commercial court, which was designed to handle disputes in the commercial sector, although currently limited to bankruptcy, delays in debt payment obligations, intellectual property rights and banking liquidation disputes in the Deposit Insurance Corporation Law, is expected to expand its competence in the future because the commercial court has exclusive substantive jurisdiction that can override the absolute authority of arbitration, and its own characteristics to improve and support Indonesia's economic activities, especially in resolving debt and credit problems fairly, quickly, openly and effectively. 
In determining an action or the exercise of judicial power, constitutional teachings require at least: ${ }^{35}$

a. That the exercise of power must be within the limits of the provisions of the law against those who are given that power and that those who exercise that power are accountable to the law;

b. That the exercise of power must be in accordance with the idea of respect for individuals and the rights of individual citizens;

c. That the powers given to institutions within a country, whether legislative, executive, and judicial institutions, must be properly distributed among the various state institutions in order to avoid abuse of power;

d. That the government in formulating policies, and the legislature, in enacting those policies, are accountable to the electorate who gave them the confidence to wield that power.

The ideal concept of the Commercial Court in realizing an independent judicial power in the settlement of commercial disputes, can be determined through 3 (three) concepts in law enforcement, namely, the concept of total law enforcement (total enforcement concept). Invitations regarding commercial courts regarding their structure, position and competence, full enforcement concept, restrictions on formal procedural law in commercial courts that are still specific in nature are spread across several laws, namely bankruptcy and suspension of debt payment obligations, intellectual property rights, and deposit insurance institutions, even still using HIR and RBG if they have not been specifically regulated, the concept of actual law enforcement (actual enforcement concept), namely there are several fields of commerce that are closely related to bankruptcy and delays in debt payment obligations and require the same handling. with these fields because they are part of the commercial sector, namely disputes in the banking sector, disputes in the insurance sector, and disputes in the capital market.

The holder of judicial power is one of the characteristics of a state based on law. Judicial power is an independent institution, meaning that this power in carrying out its duties and functions is free from the power of other institutions. However, legal corridors in the form of statutory arrangements for the implementation of judicial functions need to be carried out in order to prevent the exercise of unlimited powers of the judiciary. ${ }^{36}$

The supporting factor for strengthening the competence of the commercial court lies in the supervisory and coaching function to improve the competence of judges themselves through technical education and training of judges, legal reform in the judicial sector with a room system

35 I Dewa Gede Palguna, Pengaduan Konstitusional (Constitusional Complaint) Upaya Hukum terhadap Pelanggaran Hak-Hak Konstitusional Warga Negara, Sinar Grafika, Jakarta, 2013, page. 27.

36 Kosariza, Netty, Meri Yarni, Analisis Penyelesaian Sengketa Kewenangan Lembaga Negara Oleh Mahkamah Konstitusi, Jurnal Sains Sosio Humaniora, Vol 4 No 2 December 2020, page.547-556 
and recruitment of judges that are transparent and free of corruption, so that it is possible to reconstruct a commercial court that is focused on to the function, purpose and jurisdiction of commercial disputes.

Accountability to the judiciary at this time in Indonesia has become an urgent need to be realized immediately in order to rebuild public trust in the law and law enforcement agencies. The accountability of the judicial power is important so that the functions of the courts and the judiciary can be realized as one of the objectives of the establishment of the Republic of Indonesia as mandated in the Preamble to the 1945 Constitution, to realize justice, order, social balance and to uphold the law itself. ${ }^{37}$

The implementation of the principle of freedom of judges in deciding a case that they handle. Judges are free from the interference of extra-judicial powers, both executive and legislative powers and other extra-judicial powers in society. Judges in examining and adjudicating are free to determine their own methods of examining and adjudicating, the freedom of judges means freedom in the context of the freedom of the judiciary. The logical consequence must be that it must be interpreted that both in general and in certain cases, the leadership of the court can provide direction or guidance for judges in the form of advice or guidance, this does not reduce the meaning of judges' freedom. ${ }^{38}$

Although in principle judicial power must be independent and judges have freedom, but independent judicial power and freedom itself is not absolute in the sense of being free without limits which can actually lead to arbitrariness so of course there are restrictions on power and that freedom is a limitation of power. The judiciary which is specifically related to the authority of judges to decide and examine, (competence) in commercial courts in Indonesia.

\section{CONCLUSION}

The limitation of judicial power is based on the constitutional basis, namely Article 1 paragraph 3 of the 1945 Constitution, Article 24 of the 1945 Constitution and Article $24 \mathrm{~A}$ of the 1945 Constitution. Indonesia as a state based on Pancasila law has the goal of realizing social justice for all Indonesian people, and as a manifestation of the concept of separation or the division of powers constitutes an independent judicial power which is exercised by a Supreme Court and its subordinate judiciary and a Constitutional Court. The commercial court as a sub-system within the judicial power is a special court under the general judiciary that has different competencies from other general courts. The implementation of the limitation of judicial power in the competence of the commercial court to realize an independent judicial power is normatively spread out in various laws. These norms include legal remedies against decisions of commercial

37 Rahayu Prasetyaningsih, Akuntabilitas Kekuasaan Kehakiman, Jurnal Konstitusi, Vol.8, No 5, October 2011, page.829-848

38 Firman Floranta Adonara, Prinsip Kebebasan Hakim dalam Memutus Perkara Sebagai Amanat Konstitusi, Jurnal Konstitusi, Vol 12, No. 2 June 2015, page.217-236 
court judges that eliminate appeals, supervisory functions by the Supreme Court internally and externally and the general public, code of ethics for judges, competence of judges and commercial court institutions, commercial court procedural law. , principles and integrated components that will strengthen the commercial court. As a court that is given the authority to examine and decide disputes in the commercial sector

\section{Books:}

\section{BLIBIOGRAPHY}

Ahmad Fadlil Sumadi, 2013, Pengawasan dan Pembinaan Pengadilan Fungsi Manajemen Mahkamah Agung Terhadap Pengadilan di Bawahnya Setelah Perubahan UUD 1945, Setara Press, Malang;

Antonius Sudirman, 2007, Hati Nurani Hakim dan Putusannya Suatu Pendekatan Dari Perspektif Ilmu Hukum Perilaku (Behavioral Jurisprudence) Kasus Hakim Bismar Siregar, Citra Aditya Bakti, Bandung;

Budiono Kusumohamidjojo, 2016, Teori Hukum Dilema antara Hukum dan Kekuasaan, Yrama Widya, Bandung;

Dahlan Sinaga, 2015, Kemandirian dan Kebebasan Hakim Memutus Perkara Pidana dalam Negara Hukum Pancasila Suatu Perspektif Teori Keadilan Bermartabat, Nusa Media, Bandung;

Donald Black, 1976, The Behaviour of Law, Academic Press, New York USA;

Gregory Leyh, 2008, Hermeneutika Hukum, Nusa Media, Bandung;

Herlien Budiono, 2006, Asas Keseimbangan Bagi Hukum Perjanjian Indonesia: Hukum Perjanjian Berlandaskan Asas-Asas Wigati Indonesia, Citra Aditya Bakti, Bandung;

I Dewa Gede Palguna, 2013, Pengaduan Konstitusional (Constitusional Complaint) Upaya Hukum terhadap Pelanggaran Hak-Hak Konstitusional Warga Negara, Sinar Grafika, Jakarta;

Jimly Asshidiqie, 2006, Konstitusi dan Konstitusionalisme Indonesia, Sekretariat Jenderal dan Kepaniteraan Mahkamah Konstitusi, Jakarta;

Jogi Nainggolan, 2015, Energi Hukum sebagai Faktor Pendorong Efektivitas Hukum, Refika Aditama, Bandung;

K. Wantjik Saleh, 1977, Kehakiman dan Peradilan, Ghalia Indonesia, Jakarta;

Kaelan, 2009, Filsafat Pancasila Pandangan Hidup Bangsa Indonesia, Paradigma, Yogyakarta;

Lawrence Friedman, 1984, American Law, An Introduction, W.W. Norton \& Company, New York;

M. Yahya Harahap, 2008, Kekuasaan Mahkamah Agung Pemeriksaan Kasasi dan Peninjauan Kembali Perkara Perdata, Sinar Grafika, Jakarta; 
Majelis Permusyawaratan Rakyat Republik Indonesia, 2010, Panduan Pemasyarakatan Undang-Undang Dasar Republik Indonesia Tahun 1945 (Sesuai dengan urutan Bab, Pasal dan ayat), Sekretaris Jendral MPR RI, Jakarta;

Moh.Mahfud MD., 2011, Membangun Politik Hukum, Menegakkan Konstitusi, Raja Grafindo Persada, Jakarta;

Piatur Pangaribuan dan Arie Purnomosidi, 2014, Negara Hukum Pancasila dalam Kerangka NKRI, Cakrawala Media, Surakarta;

Ridwan, 2012, Reorientasi Penggunaan Diskresi: Kajian tentang Kontrol Penyelenggaraan Pemerintahan Melalui Pejanjian Kebijakan (Beleidsovereenkomst), Disertasi, Program Doktor Ilmu Hukum Universitas Diponegoro, Semarang;

Rimdam, 2012, Kekuasaan Kehakiman Pasca-Amandemen Konstitusi, Kencana Prenada Media Group, Jakarta;

Rusli Muhammad, 2013, Lembaga Pengadilan Indonesia Beserta Putusan Kontroversial, UII Press, Yogyakarta;

Soetandyo Wignjosoebroto, 2002, Hukum Paradigma, Metode dan Dinamika Masalahnya, ELSAM-HUMA, Jakarta;

Zaenal Ma'arif, 2015, Politik dan Peradilan Sikap dan Tanggapan Kekuasaan Eksekutif terhadap Putusan Pengadilan di Bidang Politik, Genta Publishing, Yogyakarta.

\section{Journals:}

Bagir Manan, Prasyarat Kemerdekaan Kekuasaan Kehakiman, Varia Peradilan Majalah Hukum Year XXX No.348 November 2014;

Dachran Busthami, Kekuasaan Kehakiman dalam Perspektif Negara Hukum di Indonesia, Masalah-Masalah Hukum, Vol. 46 No. 4, October 2017;

Faridy, Menuju Kekuasaan Kehakiman Yang Bebas dan Mandiri, HAKAM, Vol 02 No 02, December 2018;

Firman Floranta Adonara, Prinsip Kebebasan Hakim dalam Memutus Perkara Sebagai Amanat Konstitusi, Jurnal Konstitusi, Vol 12, No. 2 June 2015;

Hilario G.Davide, Jr.,Comments on the Paper of Hon. Andrew Kwok Nang Li, Chief Justice of the Court of Final Appeal of the Hongkong Special Administrative Region of the People $S$ Republic of China, Conference of Chief Justices of Asia and Pacific, 18th Law Asia Conference, Seoul, 8 September 1999;

Kosariza, Netty, Meri Yarni, Analisis Penyelesaian Sengketa Kewenangan Lembaga Negara Oleh Mahkamah Konstitusi, Jurnal Sains Sosio Humaniora, Vol 4 No 2 December 2020;

Rahayu Prasetyaningsih, Akuntabilitas Kekuasaan Kehakiman, Jurnal Konstitusi, Vol.8, No 5, October 2011; 